\title{
THE IMPLICATIONS OF CULTURAL AWARENESS IN MILITARY ENVIRONMENT
}

\author{
Lucian ISPAS \\ "Nicolae Bălcescu" Land Forces Academy, Sibiu, Romania \\ ispaslucian04@yahoo.com,
}

\begin{abstract}
Cultural awareness helps people to understand the impact of culture on people's believes and behaviours offer the ability to discover and be aware of the effects of culture, and requires an understanding of the necessity to consider cultural terrain in military operations, an important source of intelligence that is consist of cultural factors for planning and accomplishing such operations that take into considerations not only civilians but military.
\end{abstract}

\section{Keywords: cultural, customs, behaviors, awareness}

The new features of conflicts that take place in the current security environment makes us look more closely and more responsibility to the human communities in the area of military actions. Carrying out missions in theaters of operations requires accurate knowledge of the factors that influence their achievement, amongst which the local community occupies a very important place.

Globalization, the dissolution of borders, the expansion of science and technology, the enlargement of telecommunication networks (Internet, phone, media) have enhanced the interaction between people from different cultures. The myth of the monocultural community has been by the dynamics of a society whose development tends to create one single nation, encompassing the entire globe and forming a single entity in which the emphasis is placed on the harmonious development under the umbrella of the acceptance of the cultural diversity.

\begin{abstract}
1. Introduction to cultural awareness

Each community has formed specific traits and characteristics which provide a distinct individuality and personality in relation to other local communities. There are places where the local power takes on and enhances government policies in their totality, but we can equally observe the "supremacy" of the local authority in relation to the government. If the former is characteristic to local communities in democratic countries, the latter is specific to developing states. In these communities the power and influence of local leaders and of the traditional leadership structures is strongly present and manifested.

"Cultures are characterized by a shared set of beliefs, values, norms and symbols that unite a group. These beliefs may come from many sources, such as a person's background, family, education, religion or history. Understanding the beliefs and values of a local population is critical for effective information operations. Failure to respect or understand the beliefs
\end{abstract}


of a local population can result in serious hostility towards military intervention and attacks upon military personnel. Likewise, information operations that assume the foreign audience shares the same jokes, history, or values that Soldiers and Marines do frequently fail to deliver messages effectively" [1].

In situations specific to various theaters of operations, adequately identifying and knowing the features and characteristics of human communities in the area of responsibility ensures the prerequisites for solving the problems they are experiencing, and the successful accomplishment of the tasks entrusted.

The experience in Afghanistan has provided sufficient evidence that the planning and execution of specific actions in different theaters of operations, correct identification and awareness of the customs and culture of these territory, adequate management of the relations of cooperation with local communities, has been and will continue to remain one of the best solutions for executing the mission.

Focusing towards attracting the local population ask for the military to reconsider a different type of planning, in areas adjacent to the military, and the necessity to deploy trained people and experts of the cultural particularities in which the military operates is evident.

Imposing a specific culture or replacing national values with the Western ones has never been one of the objectives of the intervention forces, at least not a declared one, but it is obvious that differences have reached to cultural disputes and irrecoverable ruptures in terms of the relationships with the local population.

A first step towards awareness of the impact of the cultural component in the success of missions is represented by an integrated approach of the concepts that configure the specificity of the cultural environment.

Research has demonstrated that cultural decisions based on cultural issues do not always have the most wanted effect; many uninspired decisions are the result of cultural lack of knowledge. There are several ways to improve cultural awareness in the military field with the help of military, civilian experts, or a mixture thereof.

However, there is uncertainty. For example, cultural experts suggest that civilian anthropologists could contribute to obtaining the desired effect, but they must overcome a historical period of mistrust and disillusionment regarding the military institution, mistrust that could represent an obstacle for cooperation. The solution can reside in possessing basic knowledge about the foreign cultures, so that policymakers understand and take into account the religious, familial and tribal interactions characteristic to the foreign communities. The more aware of the culture of the opponent, the better we can prevent or reduce the duration and cost of current and future conflicts.

There are several exceptions and reserves to be considered, especially where culture is used to predict the military actions of different nations or nation-states. Throughout history, there have been many cultural errors in terms of military operations. In Good Anthropology, Bad History: The Cultural Turn in Studying War, Patrick Porter, a prominent Australian anthropologist, suggests "caution in implementing cultural stereotypes in contrast with sound military planning. There are too many exceptions and qualifications that must be made between the eastern and western ways of war" [2].

Porter's study gives examples where military decisions were taken based on a judicious judgment, but without taking cultural patterns into account. Generally, his article serves as a warning to the US military. As the US Defense Ministry redirects some of its resources intended for "advanced technology" towards cultural awareness, planners and policymakers should not forget that there are no simple or temporary solutions in the current or future 
wars. Although Porter argues the need for a profound cultural awareness, he advises the Ministry of Defense of the United States to "proceed with caution".

In the same vein, in the American Naval Institute magazine, US General Robert H. Scales Jr. wrote that "the army remains devoted to the premise that success in war is best achieved by overwhelming technological advantage" [3]. Scales insist that a huge advantage can be achieved by overtaking the enemy in terms of thinking, not equipment.

This change in the concern for cultural awareness is a considerable one in what regards the manner in which the US government deals with war. Having spent the decade of the nineties for achieving advanced technology, the Ministry of Defense of the United States must now consider that victory in nowadays and future wars will require better knowledge of the reasons why people do what they usually do and how decisions are taken.

There are several solutions to this problem.

Scales argues that the core of a culture-centered approach in future wars should be a group of well-educated language proficient world scouts, who feel comfortable in strange and distant places.

The remarkable cultural anthropologist and member of the Board for Defense Policy at the Office of Naval Research, Dr. Mark Montgomery Fate, brings a few observations and field experiences to the debate on the US Ministry of Defense's task of improving cultural awareness. Mc Fate's “arguments regarding the hiring of professional anthropologists are consistent with the common trend on cultural awareness. She argues that the only way to succeed in Iraq is to understand different cultures and subcultures in the region. She also declares that the organizational structure of the insurgency is not military, but tribal" [4].

\section{Cultural component in a combat environment}

The reality of the theaters of operations in Afghanistan and Iraq has confirmed that gaining popular support faces a lot of challenges: ethnic and social division, absence of jobs, corruption, banned activities, simplicity, drug use etc. These are supplemented by the existing cultural differences and the need to correctly comprehend the cultural environment in which it the land forces operate.

In the past, military commanders have not benefit from real support from the local population, because a lack of understanding the culture and the populace in which they were operating were made.

Another concept based on decisions taken form a cultural perspective is the Human Terrain System (HTS). This alternative associates the best specialists in the fields of civil and military culture and is aimed at helping in the planning and execution of reconstruction operations in post-conflict areas.

The solution recognized and materialized by NATO forces in the current asymmetrical conflicts (Iraq and Afghanistan TO) has led to the implementation of the HTS (Human Terrain System), a structure of HTTs (Human Terrain Team) designed to support the military in terms of perception the culture and the customs of local population in the area of responsibility. These microstructures made up by specialized anthropologists and analysts aware with the cultural, economic, social, and political environment offer commanders operational and tactical intelligence to help them analyze the "human terrain" in which the land forces are acting or fighting.

The HTT leader represents the interface between the military commander and the local community and his tasks and the attributions of the team members pursue five essential tasks: "cultural preparation of the operational environment (CPOE), the integration of the socio-cultural profile in Military Decision Making Process, participation in current operations, 
estimating the effects of the cultural dislocation in the operational environment.training the forces regarding socio-cultural issues that may occur during military action" [5].

In consequence, an intense activity is required in order to shape the sociocultural profile of the local population by conducting a complex and more accurate analysis than the beliefs made by the troops in the field, by enhancing the information used in operation planning and suggesting non-lethal courses of action that protect the population.

Direct participation in meetings with key leaders of the community requires conducting interviews, gaining intelligence, subsequent preparation of KLE (Key Leaders Engagement). Creating or strengthening relationships with local communities are required to advise the commander in a timely manner on the identified socio-cultural aspects.

\section{Conclusions}

The action of the multinational coalitions to reduce outbreaks of instability in the world leads to a concentration in a forward operational base of soldiers who socialized in different cultural environments, and who, for a limited period of time, are forced to engage in common activities. This confirms the fact that the training the specific skills related to multicultural awareness must be in the attention of deployable structures, of military educational institutions, since we cannot speak of independent actions assumed by an army outside the state borders. The relations between individuals from different cultures, estimating the impact of military activities and choosing courses of action to avoid cleavages due to inevitable cultural clashes must be a continuous process.

Since contact with the population is performed by combat forces and not by the senior commanders responsible for military decision making, it is necessary to anchor the leaders of the military microstructures (squad, platoon, company leaders) to the values of the local culture, to teach them to analyze and to evaluate the legacy of "the other", to avoid ethnocentrism, convention, pattern or prejudices that conduct to the formation of negative attitudes (suspicion, disapproval, animosity).

Moreover, there is also the need for a professionalized training of the troops in what concerns the specificity of international missions, in which knowing the local communities plays a distinct role. These are increasingly becoming active participants and with great power to influence the performance of the tasks conducted by the military and not only, in those areas of particular interest to local, regional and international peace and security.

\section{References}

[1] FM 3-24 MCWP 3-33.5 Insurgencies And Countering Insurgencies, Headquarters Department of the Army Washington, DC, 2 June 2014, 3-4, on https://fas.org/irp/doddir/army/fm3-24.pdf.

[2] Patrick Porter, Good Anthropology, Bad History: The Cultural Turn in Studying War, Parameters 40, Summer 2007, p.45,

[3] Robert H. Scales, Jr., Culture Centric Warfare, Proceedings: U.S. Navy Institute 130, October 2004, p. 32.

[4] Montgomery McFate, Anthropology and Counterinsurgency: The Strange Story of Their Curious Relationship, Military Review 85,March-April 2005, p. 24

[5] Human Terrain Team Handbook, HTS Doctrine Development, September 2008 p. 24-27, on http://www.vho.org/aaargh/fran/livres9/humterrainhandbo.pdf,. 